\title{
Movement behaviour and mortality in invasive and indigenous mussels: resilience and resistance strategies at different spatial scales
}

\author{
K. R. Nicastro ${ }^{1,2, *, * *}$, G. I. Zardi ${ }^{1,2, * *}$, C. D. McQuaid ${ }^{1}$ \\ ${ }^{1}$ Department of Zoology and Entomology, Rhodes University, Grahamstown 6140, South Africa \\ ${ }^{2}$ Present address: CCMAR-CIMAR Laboratório Associado, Univ. Algarve, Gambelas, 8005-139 Faro, Portugal
}

\begin{abstract}
The responses of indigenous and exotic species to environmental factors can differ across spatial and temporal scales, and it is this difference that determines invasion success and the dynamics of co-existence. In South Africa, the indigenous Perna perna and the invasive Mytilus galloprovincialis are the dominant intertidal mussels on the southern coast, where they co-exist. We compared their movement behaviour over 6 mo at small scales (within and at the edge of mussel beds) and at meso scales (in bays and on the open coast). M. galloprovincialis moved more and had higher mortality rates than did P. perna. For both species, mortality was greater at the edge than at the centre of beds, and on the open coast than in bays. Mussels at the edge of beds moved more than those within beds, but, while this was true for M. galloprovincialis in both habitats, $P$. perna did not show a position effect on the open coast. Cross-correlation analysis showed that movement rates of both species were correlated with mortality rates after a lag of 1 mo. These results suggest that following mortality events, mussels react to increased availability of space and decreased attachment to neighbours by increasing their movement to reorganise into a safer arrangement. However, P. perna and M. galloprovincialis effectively adopt resistance and resilience strategies, respectively. The effectiveness of each strategy depends on environmental conditions in different habitats, influencing the possibility of co-existence. The higher hydrodynamic stresses experienced in open coast habitats and at the edge of a mussel bed are disadvantageous to the more active, less strongly attached invasive species.
\end{abstract}

KEY WORDS: Invasive species - Behaviour - Mussel - Open coast - Mytilus galloprovincialis · Perna perna

\section{INTRODUCTION}

The responses of invasive alien species to variations in time and space of resources, natural enemies and the physical environment of the invaded community are determinants promoting or inhibiting the establishment and the spread of an invader (Moyle \& Light 1996, Chesson \& Huntly 1997, Davis et al. 2000, Mack et al. 2000). Consequently, differences in responses between native and invasive species can play a crucial role in setting patterns of co-existence (Chesson \& Huntly 1997).

The European or Mediterranean mussel Mytilus galloprovincialis is a successful invader worldwide, and is the most successful marine invasive species in South Africa (Branch \& Steffani 2004, Robinson et al. 2005). On the south coast of South Africa, it co-exists with the indigenous brown mussel Perna perna on the low intertidal zone of rocky shores (referred to here as the mussel zone) and both species are often arranged in very dense single or multilayered mussel beds (authors' pers. obs.). The upper and lower areas of the mussel zone are dominated by $M$. galloprovincialis and $P$. perna, respectively, while the 2 species overlap in the mid-mussel zone (Bownes \& McQuaid 2006).

Previous studies have shown that these species often respond differently to environmental harshness and that this has ecological effects on their distribution and 
partial habitat segregation. Morphological and physiological differences, such as a wider shell shape, a lower attachment strength, poorer tolerance of thermal stress and a higher expression of heat shock proteins of the invasive Mytilus galloprovincialis will favour the indigenous species during high hydrodynamic and heat stress (Zardi et al. 2007, authors' unpubl. data). However, the ecological success of $M$. galloprovincialis as an invader is mainly due to high reproductive output and re-colonisation rates (van Erkom Schurink \& Griffiths 1991, Erlandsson et al. 2006). Differences in behavioural responses of indigenous species and invaders can also determine whether invasion is promoted or inhibited (Petren \& Case 1996, Schneider et al. 2005). Previous laboratory experiments comparing the behavioural responses of Perna perna and M. galloprovincialis to the risk of predation underlined the greater mobility of the invasive species, which crawled farther and generally aggregated more (Nicastro et al. 2007).

Spatial diversity and temporal fluctuations of environmental factors can occur across large or small patches and over short and long time scales, respectively (Levins 1968). Bays are a common feature of the world's coastlines, and bay habitats usually differ physically from adjacent coastal habitats (Stauber 1950, Loosanoff \& Nomejka 1951). Intertidal organisms in bays often face lower flow velocities and physical disturbance in contrast to individuals in open coast habitats (Ricketts \& Calvin 1968, Castilla et al. 2002, Largier 2004). At a smaller scale, breaking waves can expose intertidal mussels to different forces due to the water's velocity, drag and lift (Denny 1995). Lift force is the main hydrodynamic force exerted on mussels living tightly packed in mussel beds (Denny 1987), while mussels living outside beds are mainly subjected to drag forces acting in the direction of flow (Bell \& Gosline 1997). Wave exposure can influence the structure of mussel beds (Hammond \& Griffiths 2004), and mussels react to different hydrodynamic forces by varying their attachment strength, while individuals sheltered within a bed have lower attachment strength than those living outside the bed or at its fringe (Witman \& Suchanek 1984, Bell \& Gosline 1997, Zardi et al. 2006). However, the greater strength of attachment of individuals living outside a bed is usually not enough to compensate for the higher hydrodynamic load, making this position less secure (Zardi et al. 2006). Mussels clump together to form large dense beds that play a major role as primary space holders in the intertidal habitat (Seed \& Suchanek 1992). Adult mussels are able to move over short distances, making a mussel bed a dynamic structure composed of constantly rearranging individuals (e.g. Paine \& Levine 1981, Schneider et al. 2005), and laboratory studies have suggested that different movement strategies could influence species-specific mortality rates (Schneider et al. 2005).

Movement of Mytilus galloprovincialis and Perna perna was investigated in the field over a period of 6 mo, comparing mussel behaviour in sheltered bays and on the more wave-exposed open coast. Within each of these habitats, we compared mussels at the edge and at the centre of beds. We tested the hypotheses that (1) due to generally higher hydrodynamic stress, mussels at open coast sites will experience higher mortality rates and, consequently, they will continuously adjust their position, looking for a protected, more secure arrangement; $(2)$ mussels at the centre of a clump will be subjected to lower mortality rates and will move less than mussels at the edge of a clump, where individuals are less constrained by other mussels; (3) the indigenous mussel will move less than the invasive species, adopting a less dynamic strategy, as previous studies have shown that $P$. perna has a higher attachment strength than M. galloprovincialis.

\section{MATERIALS AND METHODS}

Mussel movement. Mussel movement was measured in 2 bays, Plettenberg Bay $\left(34^{\circ} 00^{\prime} 17^{\prime \prime} \mathrm{S}, 23^{\circ} 27^{\prime} 17^{\prime \prime} \mathrm{E}\right)$

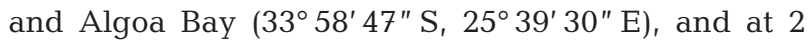
open coast sites, Robberg $\left(34^{\circ} 06^{\prime} 14^{\prime \prime} \mathrm{S}, 2^{\circ} 23^{\circ} 07^{\prime \prime} \mathrm{E}\right)$ and Cape Recife ( $34^{\circ} 02^{\prime} 27^{\prime \prime} \mathrm{S}, 25^{\circ} 32^{\prime} 01^{\prime \prime}$ E). Each site had 2 locations $200 \mathrm{~m}$ apart at which digital pictures of 12 quadrats $(20 \times 20 \mathrm{~cm})$ were taken monthly for $6 \mathrm{mo}$. In each quadrat, 6 individuals of each species (identified by shell shape and colouring) were selected from mussels in the centre of monolayer mussel beds and another 6 individuals from mussels living at the edge (4 to $5 \mathrm{~cm}$ in shell length). For each selected mussel, the net displacement (crawling distance) was recorded every month by superimposing photographs of fixed quadrats. Data on the total distances crawled by mussels in 6 mo fulfilled the pre-requisites for parametric analysis (Cochran's test) and were analysed using separate 5-factor nested ANOVA (GMAV5 software) to investigate the effects of Species (Perna perna or Mytilus galloprovincialis, fixed factor) and Position in the bed (centre or edge, fixed factor) on movement. In both cases the other 4 factors were Habitat (bays or open coast, fixed factor), and Sites nested within Habitat, Location nested within Sites and Quadrat nested within Location (all random factors).

Mussel mortality. Mortality rates of Perna perna and Mytilus galloprovincialis were measured at the same 2 locations at the same sites, based on the digital pictures of quadrats described above. Every month, in each quadrat, 10 individuals were selected from mussels in the centre of mussel beds and another 10 mussels from 
those living at the edge. Mortality was assessed by comparing digital pictures for consecutive months. The mortality data for quadrats fulfilled the requirements for parametric analysis (Cochran's test) and were analysed using nested ANOVA (GMAV5 software) with Position, Species and Habitat as fixed factors, and Site and Location as nested random factors.

Cross-correlation. Mean monthly movement of each species in bays and on the open coast was crosscorrelated with mean monthly mussel mortality rate using various lags from +6 to -6 mo for movement.

\section{RESULTS}

\section{Mussel movement}

Crawling distance varied monthly, showing a similar pattern for both species. There was a rapid increase in mean crawling distance in March (autumn) and a decrease in the following months (Fig. 1a,b). Mytilus galloprovincialis generally crawled farther than Perna perna, but in the analysis of effects of species (Table 1) there was a significant Species $\times$ Site interaction, as the difference was non-significant at one site. In bays, $M$. galloprovincialis crawled 75 and $56 \%$ more than $P$. perna for individuals living at the edge and in the centre of mussel beds, respectively, while on the open coast, the equivalent values were 65 and $61 \%$.

Position also had a strong effect on movement (Table 2). There was a Position $\times$ Site effect and a Position $\times$ Location effect, but in both cases the interaction reflected a difference of degree. At all sites edge had a greater effect than centre, but the effect was stronger at some sites than others, while at all locations edge also had a greater effect than centre, but again the effect was stronger at some locations. Movement was greater for both species in bays than on the open coast, but the ef-
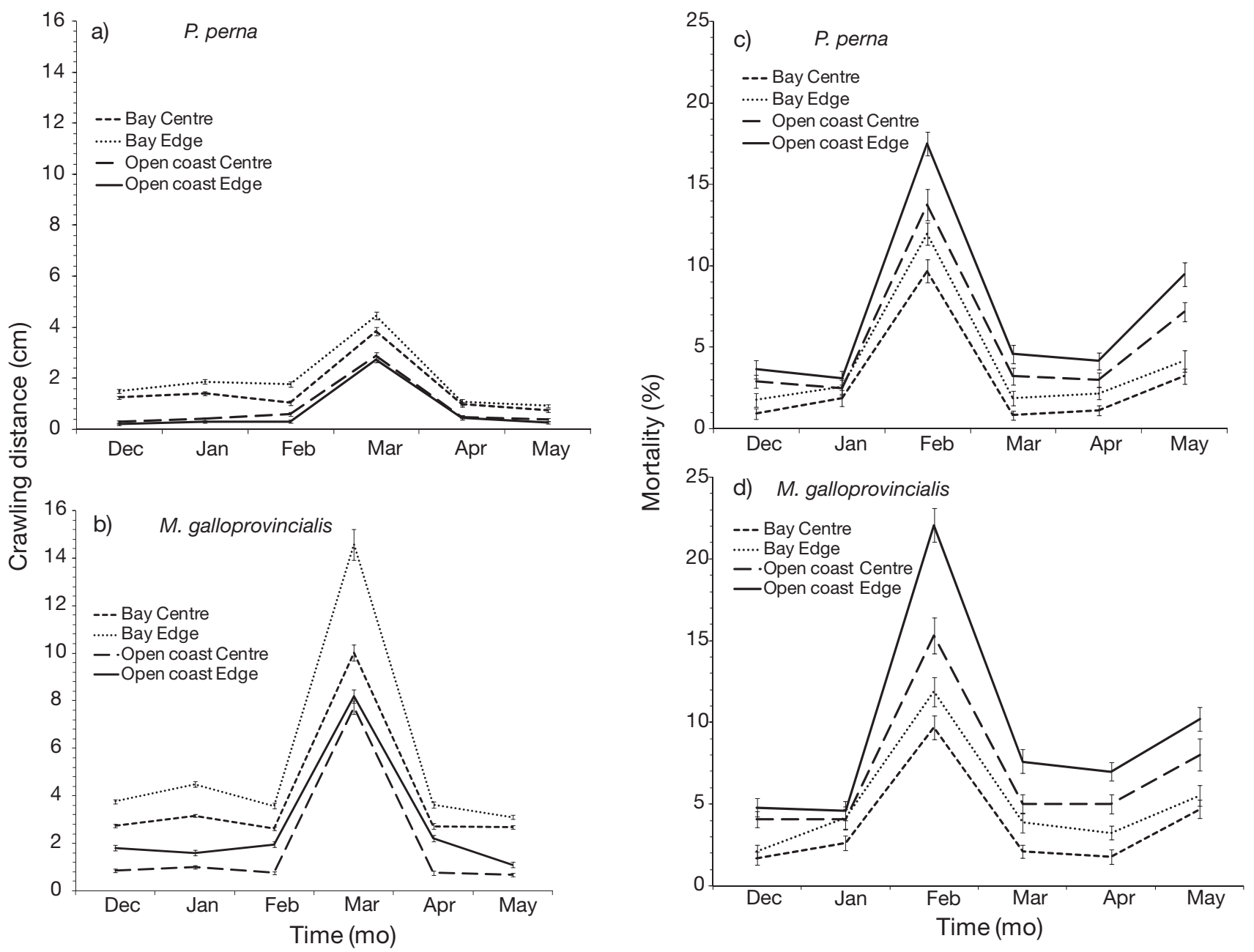

Fig. 1. Mytilus galloprovincialis and Perna perna. Mean $( \pm \mathrm{SE})$ monthly $(\mathrm{a}, \mathrm{b})$ crawling distance and $(\mathrm{c}, \mathrm{d})$ mortality for $(\mathrm{a}, \mathrm{c})$ $P$. perna and (b,d) M. galloprovincialis at the centre and at the edge of a mussel bed, in bays and on the open coast 
Table 1. Mytilus galloprovincialis and Perna perna. Results of 5 -factor nested ANOVA to investigate the effects of Species (P. perna or M. galloprovincialis) on movement after 6 mo

\begin{tabular}{|c|c|c|c|c|}
\hline Source of variation & $\mathrm{df}$ & MS & $F$ & $\mathrm{p}$ \\
\hline Habitat & 1 & 58994.34 & 11.94 & 0.0745 \\
\hline Site (Habitat) & 2 & 4939.88 & 32.75 & $<0.01$ \\
\hline Location (Habitat × Site) & 4 & 150.86 & 7.19 & $<0.0001$ \\
\hline Species & 1 & 110722.56 & 144.23 & $<0.01$ \\
\hline $\begin{array}{l}\text { Quadrat (Habitat } \times \\
\text { Site } \times \text { Location) }\end{array}$ & 88 & 20.99 & 1.3 & $<0.05$ \\
\hline Habitat $\times$ Species & 1 & 10416.75 & 13.57 & 0.0664 \\
\hline Species $\times$ Site (Habitat) & 2 & 767.67 & 47.68 & $<0.01$ \\
\hline $\begin{array}{l}\text { Species } \times \text { Location } \\
(\text { Habitat } \times \text { Site })\end{array}$ & 4 & 16.1 & 1.27 & 0.2067 \\
\hline $\begin{array}{l}\text { Species } \times \text { Quadrat (Habi- } \\
\text { tat } \times \text { Site } \times \text { Location) }\end{array}$ & 88 & 12.65 & 0.78 & 0.067 \\
\hline Residual & 112 & 16.19 & & \\
\hline
\end{tabular}

fect of Habitat was non-significant $(p=0.0745)$ in both analyses. When movement was analysed separately for each species, each showed a non-significant habitat effect $(\mathrm{p}=0.07$ for $M$. galloprovincialis and $\mathrm{p}=0.08$ for Perna perna), with individuals in bays crawling farther than mussels on the open coast, regardless of their position in the bed. M. galloprovincialis at the edges of beds always crawled significantly farther than mussels within beds, but the effect was stronger at some sites and locations than others (Position $\times$ Site, $\mathrm{p}<0.05$; Position $\times$ Location, $\mathrm{p}<0.01)$. P. perna showed the same effect of position, but only in bays (Position $\times$ Habitat, $\mathrm{p}<0.05$ )

\section{Mussel mortality}

Mussel mortality fluctuated seasonally and the highest mortality rates were reached in February (late summer) for both species, both on the open coast and in bays (Fig. 1c,d).

There were strong effects of both Species (Mytilus galloprovincialis mortality > Perna perna mortality) and Habitat (open coast > bays), with a significant Species $\times$ Habitat interaction as the species difference was greater on the open coast (Table 3). Mortality rates were generally higher on the edge of mussel beds than at the centre, but the difference was not significant at 4 locations (Location $\times$ Position, $\mathrm{p}<0.05$ ).

\section{Cross-correlation}

The highest (and only significant) correlations between movement and mortality rates were positive and were observed when movement lagged 1 mo behind mortality (lag $=-1$; Fig. 2).

\section{DISCUSSION}

In general, Mytilus galloprovincialis moved significantly more than Perna perna over a period of 6 mo. Previous studies on mussel movement (Hunt \& Scheibling 2002) and on colonization and patch dynamics (Hunt \& Scheibling 1998, 2001, Schneider et al. 2005) showed that adult crawling can play a crucial role in the dynamics and structure of intertidal mussel beds. Under some circumstances space made available by mortality may be occupied by new settlers, or even

Table 2. Mytilus galloprovincialis and Perna perna. Results of 5 -factor nested ANOVA to investigate the effect of Position in the bed (centre or edge) on movement after 6 mo

\begin{tabular}{|c|c|c|c|c|}
\hline Source of variation & $\mathrm{df}$ & MS & $F$ & $\mathrm{p}$ \\
\hline Habitat & 1 & 58994.34 & 11.94 & 0.0745 \\
\hline Site (Habitat) & 2 & 4939.88 & 32.75 & $<0.01$ \\
\hline Location (Habitat × Site) & 4 & 150.86 & 7.19 & $<0.0001$ \\
\hline Position & 1 & 9000.47 & 25.13 & $<0.05$ \\
\hline $\begin{array}{l}\text { Quadrat (Habitat } \times \text { Site } \times \\
\text { Location) }\end{array}$ & 88 & 20.99 & 0.3 & $<0.0001$ \\
\hline Habitat $\times$ Position & 1 & 1811.21 & 5.06 & 0.1535 \\
\hline Position $\times$ Site (Habitat) & 2 & 358.11 & 7.71 & $<0.05$ \\
\hline $\begin{array}{l}\text { Position } \times \text { Location }) \\
(\text { Habitat } \times \text { Site }\end{array}$ & 4 & 46.42 & 7.57 & $<0.0001$ \\
\hline $\begin{array}{l}\text { Position } \times \text { Quadrat (Habi- } \\
\text { tat } \times \text { Site } \times \text { Location) }\end{array}$ & -88 & 6.13 & 0.09 & $<0.0001$ \\
\hline Residual & 2112 & 69.03 & & \\
\hline
\end{tabular}

Table 3. Mytilus galloprovincialis and Perna perna. Results of 5 -factor nested ANOVA applied to mortality rates after 6 mo

\begin{tabular}{|c|c|c|c|c|}
\hline Source of variation & $\mathrm{df}$ & MS & $F$ & $\mathrm{p}$ \\
\hline Habitat & 1 & 0.6388 & 67.3 & $<0.05$ \\
\hline Site (Habitat) & 2 & 0.0095 & 0.81 & 0.5063 \\
\hline Location (Habitat $\times$ Site) & 4 & 0.0117 & $7.07<$ & $<0.0001$ \\
\hline Position & 1 & 0.1693 & $229.28<$ & $<0.01$ \\
\hline Species & 1 & 0.1211 & $491.66<$ & $<0.01$ \\
\hline Habitat $\times$ Position & 1 & 0.0103 & 13.92 & 0.0649 \\
\hline Habitat $\times$ Species & 1 & 0.0152 & $61.67<$ & $<0.05$ \\
\hline Position × Site (Habitat) & 2 & 0.0007 & 0.19 & 0.8373 \\
\hline Species $\times$ Site (Habitat) & 2 & 0.0002 & 0.07 & 0.9347 \\
\hline $\begin{array}{l}\text { Position } \times \text { Location } \\
\text { (Habitat } \times \text { Site })\end{array}$ & 4 & 0.004 & 2.4 & $<0.05$ \\
\hline $\begin{array}{l}\text { Species } \times \text { Location } \\
\text { (Habitat } \times \text { Site })\end{array}$ & 4 & 0.0036 & 2.16 & 0.0725 \\
\hline Position $\times$ Species & 1 & 0.0044 & 9.27 & 0.0931 \\
\hline Habitat $\times$ Position $\times$ Species & 1 & 0.2243 & 0.0014 & 43.02 \\
\hline $\begin{array}{l}\text { Species } \times \text { Position } \times \text { Site } \\
\text { (Habitat) }\end{array}$ & 2 & 0.0005 & 0.14 & 0.8709 \\
\hline $\begin{array}{l}\text { Species } \times \text { Position } \times \text { Location } \\
(\text { Habitat } \times \text { Site })\end{array}$ & 4 & 0.033 & 1.98 & 0.0966 \\
\hline Residual & 352 & 0.0017 & & \\
\hline
\end{tabular}




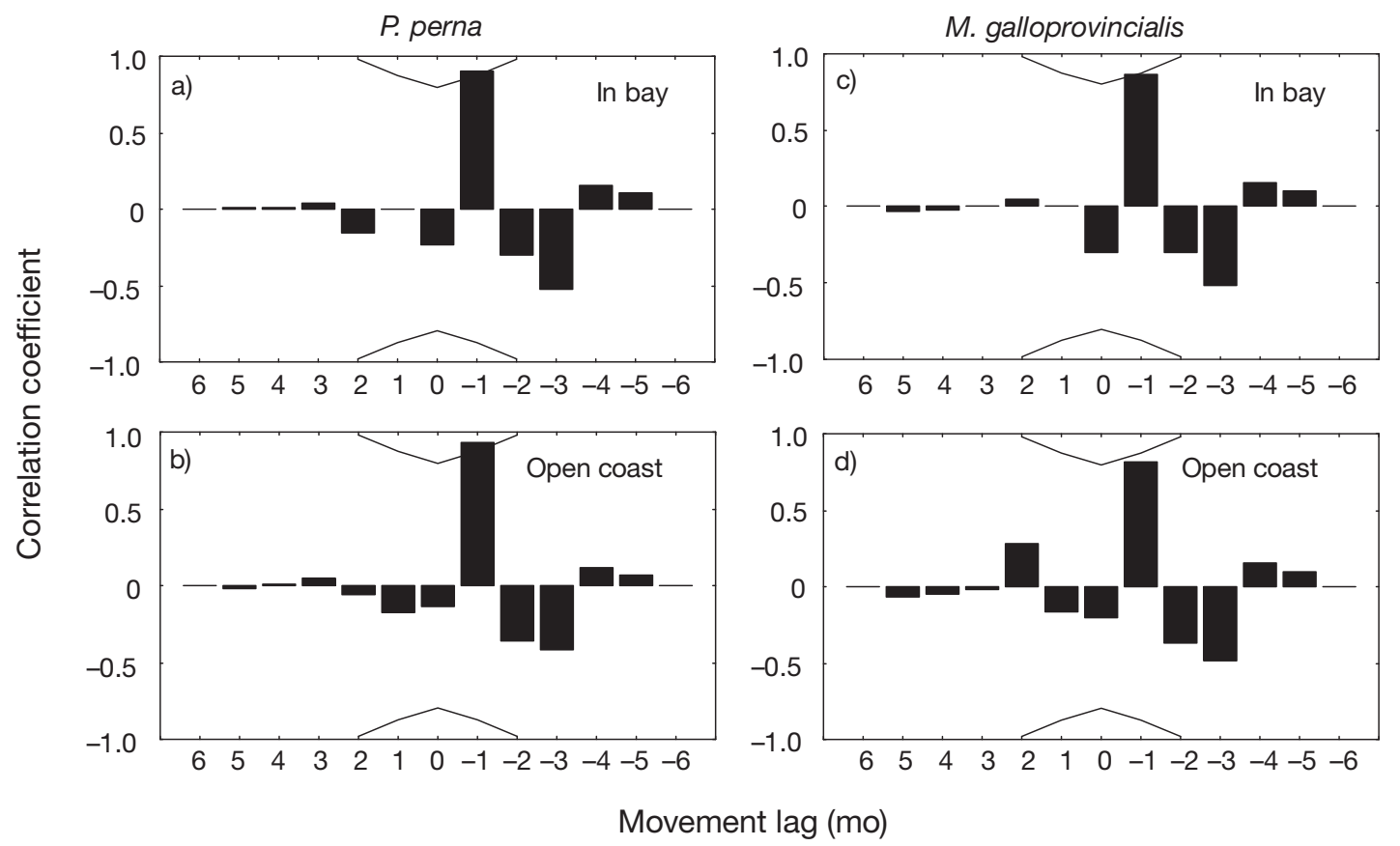

Fig. 2. Mytilus galloprovincialis and Perna perna. Cross-correlation analyses of monthly mean movement with mortality rates for $(\mathrm{a}, \mathrm{b})$ P. perna and $(\mathrm{c}, \mathrm{d})$ M. galloprovincialis in $(\mathrm{a}, \mathrm{c})$ bays and $(\mathrm{b}, \mathrm{d})$ on the open coast. Bars are correlation coefficients; curved lines are approximate $95 \%$ confidence levels for the significance of each correlation

immigrants from nearby patches. Nevertheless, our results indicate that during the study period resident survivors responded to freeing of space by increased movement. Due to the extreme spatial and temporal heterogeneity in environmental conditions of rocky intertidal habitats, even the small-scale movements observed during the field experiment are likely to subject mussels to different micro-environmental conditions (Helmuth \& Denny 2003) and could be important in regulating population dynamics. For example, Schneider et al. (2005) suggested that differences in the movement between conspecific $M$. edulis and $M$. galloprovincialis could account for observed speciesspecific differences in their survival. In our study, the more dynamic strategy adopted by $M$. galloprovincialis, together with lower attachment strength than $P$. perna (Zardi et al. 2006), could explain the higher mortality rates experienced by $M$. galloprovincialis during the 6 mo survey.

Mussels anchor themselves to the substratum by means of byssal threads (Waite 1992). When subjected to higher hydrodynamic stress, both Mytilus galloprovincialis and Perna perna increase the production of byssal threads to attach more firmly to the substratum (Zardi et al. 2007). For both species, movement was higher at bay sites than at open coast sites, possibly because the lower hydrodynamic stress experienced at bay sites allows mussels to be less strongly attached to the substratum. Furthermore, in all cases except $P$. perna on the open coast, total movement over 6 mo was higher for mussels at the edge of a bed than for mussels deep within a bed. This can be explained by tight packing and lower availability of space within beds, and by the fact that mussels inside patches are bound to the substratum by the byssal threads of their neighbours as well as their own threads.

Due to their orientation and position on the rocks, mussels in beds and solitary individuals are primarily subjected to lift and drag forces, respectively. Laboratory experiments have shown that solitary mussels tend to arrange the posterior-anterior axis parallel to the substratum and perpendicular to prevailing water flow, thus exposing a smaller area and decreasing the hydrodynamic load (Dolmer \& Svane 1994). In the field, because the flow of breaking waves is variable and unpredictable, this ideal arrangement is difficult to maintain. Zardi et al. (2006) showed that the orientation of solitary mussels to wave force is critical. On average, a solitary mussel of $4.5 \mathrm{~cm}$ (Perna perna or Mytilus galloprovincialis) in the worst position (broadside to the flow, i.e. posterior-anterior axis perpendicular to the water flow) exposes $60 \%$ more surface area than a similarly sized mussel positioned with the posterior-anterior axis parallel to the water flow, and will experience proportionally greater hydrodynamic stress. In contrast, mussels in beds lie vertical to the substratum, exposing the smallest shell area to lift, which is independent of the direction of water flow 
(Denny 1987). Consequently mussels in beds are subjected to a more predictable hydrodynamic environment (Denny 1987). Individuals living outside a mussel bed generally have higher attachment strength than those inside a bed (Witman \& Suchanek 1984, Bell \& Gosline 1997). However, this greater attachment strength is usually not enough to compensate for the higher and more variable hydrodynamic regime, making mussels outside beds more prone to dislodgement (Zardi et al. 2006). This prediction of dislodgement is confirmed in the present study: over 6 mo mortality rates for mussels at the edge of mussel beds were greater than for mussels at the centre of beds.

Unexpectedly, at the open coast sites movement rates of Perna perna did not show any significant differences between individuals at the edges and within beds. This may be explained by the higher wave action of the open coast, which would lead to higher attachment strength. Together with the low movement rates typical of $P$. perna, this could alter the general pattern, helping to explain this result. The relatively weak attachment strength of Mytilus galloprovincialis allows greater freedom of movement, but prevents the approach of resisting wave dislodgement, especially under the more extreme conditions of the open coast.

Mortality rates of both species varied seasonally, and were particularly high in February 2007, probably due to sand and/or wave stress (authors' pers. obs.); these 2 factors are often responsible for mass mortality in the intertidal zone and can generate gaps within mussel beds (Paine \& Levine 1981, Carrington 2002, Zardi et al. 2008). Thus, the availability of free space, diminished attachment to neighbours and the necessity of finding safer arrangements are likely explanations for the high movement rates observed in March 2007. This is supported by the cross-correlation analysis between monthly mean movement and mortality rates, which showed that high mortality was followed over the next month by high movement rates. Our study did not extend to cover the winter period when mortality, particularly through wave action, is likely to be especially high, but we predict that this effect will be even stronger in stormy months.

Clumping behaviour and the search of a safer arrangement can strongly influence mussel survival rates; a mussel living in a densely packed bed exploits the physical protection from hydrodynamic stress and predation offered by nearby mussels. Individuals living at the centre of a bed are more difficult for predators to catch and hold than individuals living at the bed edge or solitary mussels (Petraitis 1987, Svane \& Ompi 1993), and are, thus, subjected to lower rates of predation (Okamura 1986). In addition, mussels living outside or at the edge of a bed are subjected to higher hydrodynamic stress and a higher probability of dislodgement (Zardi et al. 2007). However, in a mussel bed, reduced food availability leads to slower growth and lower reproductive output (Okamura 1986, Fréchette et al. 1989, O'Riordan et al. 1993, Butman et al. 1994). Moreover, mussel beds can form a very dense and intricate matrix of byssal threads attaching to the substratum and linking mussels to each other. When mussel density is very high, the byssal matrix can lose contact with the substratum, resulting in a slight elevation of the mussel bed, i.e. a hummock. These hummocks are relatively easily dislodged by wave action, forming gaps (e.g. Seed \& Suchanek 1992, authors' pers. obs.).

Our hypotheses were only partially confirmed by our results: mussels at the edges of beds moved more and suffered higher mortality than individuals within a bed. However, despite higher mortality rates, mussels living on the open coast moved less than individuals in bays. It is likely that the high wave regime on the more exposed open coast drives mussels to produce large numbers of byssal threads, resulting in a safer attachment, but obliging them to be less mobile. This appears particularly to be the case for Perna perna at the edge of beds. Moreover, the comparatively wavesheltered conditions within bays are associated with lower mortality rates. This accords with the observation of higher cover of adult mussels in bays than at open coast sites (C. von der Meden unpubl. data).

However, our results confirm that position is important, with mussels at the edge of a mussel bed having more freedom of movement than the more constrained individuals within a bed. Also, as initially hypothesised, Perna perna moved less than Mytilus galloprovincialis, adopting a resistance strategy that favours safety against wave action through higher attachment strength and lower movement rates.

Mytilus galloprovincialis is a very aggressive invasive species. Within South Africa, it exhibits resistance to trematode parasites (Calvo Ugarteburu \& McQuaid 1998a,b), but also rapid growth rates over a range of water temperatures (Griffiths et al. 1992, Hockey \& van Erkom Schurink 1992), high fecundity (van Erkom Schurink \& Griffiths 1991), high recruitment rates (Harris et al. 1998) and resistance to desiccation (Hockey \& van Erkom Schurink 1992, authors' unpubl. data). These features have high energy demands that come at the cost of reduced attachment strength (Zardi et al. 2007). Waves can be the major cause of mussel stress and mortality in the intertidal zone (Paine \& Levine 1981, Steffani $\&$ Branch 2003), and the ability to resist dislodgement is an important attribute for a potentially invasive species.

Although the reproductive strategy of Mytilus galloprovincialis has played a crucial role in its ability to invade rocky shores worldwide, for example by allowing it to recolonise free space more quickly than Perna perna (Erlandsson et al. 2006), the energetic costs render it more vulnerable to wave-induced mortality 
(Zardi et al. 2007). The high hydrodynamic stresses experienced at open coast sites and at the edges of mussel beds are problematic for the more dynamic and less strongly attached invasive species. In terms of wave action, $P$. perna and $M$. galloprovincialis effectively adopt resistance and resilience strategies, respectively, the effectiveness of each strategy depending on environmental conditions. Consequently, coastal topography (i.e. bays versus the open coast) and, at smaller scales, position within a mussel bed can play a crucial role in limiting the invasive potential of M. galloprovincialis and setting patterns of coexistence with indigenous species.

Acknowledgements. This research was funded by a postdoctoral research fellowship from the Claude Harris Leon Foundation awarded to G.I.Z., Rhodes University and the National Research Foundation of South Africa. We are extremely grateful to V. Cole for assistance in the analyses. This work is based upon research supported by the South African Research Chairs Initiative of the Department of Science and Technology and National Research Foundation.

\section{LITERATURE CITED}

Bell CM, Gosline JM (1997) Strategies for life in flow: tenacity, morphometry, and probability of dislodgement of two Mytilus species. Mar Ecol Prog Ser 159:197-208

Bownes S, McQuaid CD (2006) Will the invasive mussel Mytilus galloprovincialis Lamarck replace the indigenous Perna perna L. on the south coast of South Africa? J Exp Mar Biol Ecol 338:140-151

Branch GM, Steffani CN (2004) Can we predict the effects of alien species? A case-history of the invasion of South Africa by Mytilus galloprovincialis (Lamarck). J Exp Mar Biol Ecol 300:189-215

Butman CA, Fréchette M, Geyer WR, Starczak VR (1994) Flume experiments on food supply to the blue mussel Mytilus edulis L. as a function of boundary-layer flow. Limnol Oceanogr 39:1755-1768

> Calvo-Ugarteburu MG, McQuaid CD (1998a) Parasitism and introduced species: epidemiology of trematodes in the intertidal mussels Perna perna and Mytilus galloprovincialis. J Exp Mar Biol Ecol 220:47-65

> Calvo-Ugarteburu MG, McQuaid CD (1998b) Parasitism and invasive species: effects of digenetic trematodes on mussels. Mar Ecol Prog Ser 169:149-163

Carrington E (2002) Seasonal variation in the attachment strength of blue mussels: causes and consequences. Limnol Oceanogr 47:1723-1733

Castilla JC, Lagos NA, Guinez R, Largier JL (2002) Embayments and nearshore retention of plankton: the Antofagasta Bay and other examples. In: Castilla JC, Largier JL (eds) The oceanography and ecology of the nearshore and bays in Chile. Ediciones Universidad Catolica de Chile, Santiago, p 179-203

- Chesson P, Huntly N (1997) The roles of harsh and fluctuating conditions in the dynamics of ecological communities. Am Nat 150:519-553

Davis MA, Grime JP, Thompson K (2000) Fluctuating resources in plant communities: a general theory of invasibility. J Ecol 88:528-534
Denny MW (1987) Lift as a mechanism of patch initiation in mussel beds. J Exp Mar Biol Ecol 113:231-245

Denny MW (1995) Predicting physical disturbance: mechanistic approaches to the study of survivorship on wave-swept shores. Ecol Monogr 65:371-418

Dolmer P, Svane I (1994) Attachment and orientation of $M Y$ tilus edulis L. in flowing water. Ophelia 40:63-74

Erlandsson J, Pal P, McQuaid CD (2006) Re-colonization rate differs between co-existing indigenous and invasive intertidal mussels following major disturbance. Mar Ecol Prog Ser 320:169-176

Fréchette M, Butmann CA, Geyer WR (1989) The importance of boundary-layer flows in supplying phytoplankton to the benthic suspension feeder, Mytilus edulis L. Limnol Oceanogr 34:19-36

Griffiths CL, Hockey PAR, van Erkom Shurink C, Le Roux PJ (1992) Marine invasive aliens on South African shores: implications for community structure and trophic functioning. S Afr J Mar Sci 12:713-722

> Hammond W, Griffiths CL (2004) Influence of wave exposure on South African mussel beds and their associated infaunal communities. Mar Biol 144:547-552

Harris JM, Branch GM, Elliott BL, Currie B and others (1998) Spatial and temporal variability in recruitment of intertidal mussels around the coast of southern Africa. S Afr J Zool 33:1-11

Helmuth B, Denny MW (2003) Predicted wave exposure in the rocky intertidal zone: Do bigger waves always lead to larger forces? Limnol Oceanogr 48:1338-1345

Hockey PAR, van Erkom Schurink C (1992) The invasive biology of the mussel Mytilus galloprovincialis on the southern African coast. Trans R Soc S Afr 48:123-139

Hunt HL, Scheibling RE (1998) Spatial and temporal variability of patterns of colonization by mussels (Mytilus trossulus, M. edulis) on a wave exposed rocky shore. Mar Ecol Prog Ser 167:155-169

> Hunt HL, Scheibling RE (2001) Predicting wave dislodgement of mussels: variation in attachment strength with body size, habitat, and season. Mar Ecol Prog Ser 213:157-164

Hunt HL, Scheibling RE (2002) Movement and wave dislodgment of mussels on a wave-exposed rocky shore. Veliger 45:263-267

Largier JL (2004) The importance of retention zones in the dispersal of larvae. Am Fish Soc Symp 42:105-122

Levins R (1968) Evolution in changing environments. Princeton University Press, Princeton, NJ

> Loosanoff VL, Nomejka CA (1951) Existence of physiologically different races of oysters, Crassostrea virginica. Biol Bull (Woods Hole) 101:151-156

Mack MC, Simberloff D, Lonsdale W, Evans H, Clout M, Bazzaz F (2000) Biotic invasions: causes, epidemiology, global consequences, and control. Ecol Appl 10:689-710

Moyle PB, Light T (1996) Fish invasions in California: Do abiotic factors determine success? Ecology 77:1666-1670

> Nicastro KR, Zardi GI, McQuaid CD (2007) Behavioural response of invasive (Mytilus galloprovincialis) and indigenous (Perna perna) mussels exposed to risk of predation. Mar Ecol Prog Ser 336:169-175

Okamura B (1986) Group living and the effects of spatial position in aggregations of Mytilus edulis. Oecologia 69: 341-347

O'Riordan CA, Monismith SG, Koseff JR (1993) A study of concentration boundary-layer formation over a bed of model bivalves. Limnol Oceanogr 38:1712-1729

Paine RT, Levine SA (1981) Intertidal landscapes: disturbance and the dynamics of pattern. Ecol Monogr 51:145-178

Petraitis PS (1987) Immobilization of the predatory gastropod, 
Nucella lapillus, by its prey, Mytilus edulis. Biol Bull (Woods Hole) 172:307-314

Petren K, Case TJ (1996) An experimental demonstration of exploitation competition in an ongoing invasion. Ecology 77:118-132

Ricketts EF, Calvin J (1968) Between Pacific tides, 4th edn revised by Hedgpeth JW. Stanford University Press, Palo Alto, CA

Robinson TB, Griffiths CL, McQuaid CD, Rius M (2005) Marine alien species of South Africa - status and impacts. Afr J Mar Sci 27:297-306

Schneider KR, Wethey DS, Helmuth BST, Hilbish TJ (2005) Implications of movement behaviour on mussel dislodgement: exogenous selection in a Mytilus spp. hybrid zone. Mar Biol 146:333-343

Seed R, Suchanek TH (1992) Population and community ecology of Mytilus. In: Gosling EG (ed) The mussel Mytilus: ecology, physiology, genetics and culture. Elsevier, New York, p 87-169

Stauber LA (1950) The problem of physiological species with special reference to oysters and oyster drills. Ecology 31: 109-118

Steffani CN, Branch GM (2003) Growth rate, condition, and shell shape of Mytilus galloprovincialis: responses to wave exposure. Mar Ecol Prog Ser 246:197-209

Svane I, Ompi M (1993) Patch dynamics in the beds of the

Editorial responsibility: Lisandro Benedetti-Cecchi, Pisa, Italy blue mussel Mytilus edulis: effect of site, patch size and position within a patch. Ophelia 37:187-202

van Erkom Schurink C, Griffiths CL (1991) A comparison of reproductive cycles and reproductive output in four southern African mussel species. Mar Ecol Prog Ser 76:123-134

Waite JH (1992) The formation of mussel byssus: anatomy of a natural manufacturing process. In: Case ST (ed) Biopolymers, Vol 19. Results and problems in cell differentiation. Springer-Verlag, Berlin, p 27-54

> Witman JD, Suchanek TH (1984) Mussel in flow: drag and dislodgement by epizoans. Mar Ecol Prog Ser 16:259-268

> Zardi GI, Nicastro KR, McQuaid CD, Rius M, Porri F (2006) Hydrodynamic stress and habitat partitioning between indigenous (Perna perna) and invasive (Mytilus galloprovincialis) mussels: constraints of an evolutionary strategy. Mar Biol 150:79-88

Zardi GI, McQuaid CD, Nicastro KR (2007) Balancing survival and reproduction: seasonality of wave action, attachment strength and reproductive output in indigenous Perna perna and invasive Mytilus galloprovincialis mussels. Mar Ecol Prog Ser 334:155-163

Zardi GI, Nicastro KR, McQuaid CD, Erlansson J (2008) Sand and wave induced mortality in invasive (Mytilus galloprovincialis) and indigenous (Perna perna) mussels. Mar Biol 153:853-858

Submitted: February 7, 2008; Accepted: July 28, 2008 Proofs received from author(s): November 12, 2008 